\title{
NUMERICKÁ ANALÝZA NESYMETRICKÉHO POUŽITIA AKČNÝCH PRVKOV MEMBRÁNOVEJ KONŠTRUCKIE
}

\author{
NUMERICAL ANALYSIS OF ASYMMETRICAL USE OF ACTUATORS \\ ON A MEMBRANE STRUCTURE
}

\author{
Lukáš Kapolka ${ }^{*}$, , Lenka Štulerová ${ }^{1}$
}

${ }^{*}$ lukas.kapolka@tuke.sk

${ }^{1}$ Technická Univerzita v Košiciach, Stavebná fakulta, 04200 Košice, Slovensko

\begin{abstract}
Abstrakt
Tento príspevok je zameraný na numerickú analýzu adaptívnej membránovej štruktúry, ktorej model bol vytvorený na základe experimentálneho zariadenia v laboratóriu. Bol skúmaný vplyv asymetrického použitia akčných členov na membránovú štruktúru bez konštrukčného zat’aženia. Výsledky článku popisujú správanie sa numerického modelu. Výsledky získané z numerického modelu budú v budúcnosti porovnané $\mathrm{s}$ výsledkami nameranými z experimentálneho zariadenia.
\end{abstract}

\section{Klíčová slova}

membránové konštrukcie, akčné prvky, numerická analýza

\begin{abstract}
This paper is focused on the numerical analysis of an adaptive membrane structure, the model of which was created on the basis of experimental device in the lab. It was researched out the effect of asymmetric use of actuators on the membrane structure without structural loads. Results of the article describe the behaviour of numerical model. The results gained from numerical model will be compared in the future with the results measured out from the experimental device.
\end{abstract}

\section{Key words}

membrane structures, actuators, numerical analysis

\section{1 ÚVOD}

Membránové konštrukcie, ako konštrukčná kategória, sú, špeciálnou formou l’ahkých povrchových štruktúr, ktoré zahŕňajú škrupiny, kupoly a lanové siete. V každom z nich je súvislý priestorovo zakrivený povrch kritickým a integrálnym konštrukčným prvkom. V t’ahaných konštrukciách môžu tieto povrchové prvky, pozostávajúce zo štruktúrnej tkaniny a vysokopevnostných káblov, prenášat' zat’aženie iba v t’ahu [1].

Primárna výhoda t’ahaných prvkov oproti tlačeným prvkom je, že môžu byt' také tenké a l'ahké, ako to ich pevnost' v t'ahu dovol'uje. V dôsledku toho je hmotnost' t'ahaných štruktúr takmer zanedbatel'ná. Ďalšou výhodou tenkých, l'ahkých t'ahových komponentov je to, že sa dajú l'ahko prepravovat' a stavat'. Laná môžu byt' dlhé desiatky metrov a nevyžadujú žiadne spoje. Môžu byt' zdvihnuté a pripojené k ich koncovým podperám pomocou žeriavov, navijakov alebo helikoptér, ktoré nevyžadujú žiadne lešenie. V skutočnosti je čas montáže membránovej štruktúry ovel'a kratší ako pri konvenčnej štruktúre [2].

Na to, aby membránová konštrukcia fungovala, sú potrebné minimálne štyri oporné body, o jeden viac, než je potrebné pre pevný konštrukčný systém. Najzákladnejšou formou je teda štvorbodová štruktúra. Jeden zo štyroch bodov musí byt' umiestnený mimo rovinu definovanú ostatnými tromi bodmi, aby sa dosiahol dvojitý zakrivený povrch, ktorý dáva konštrukcii jej stabilitu a jej schopnost’ prenášat' zat’aženie [3].

V dôsledku nízkej konštrukčnej, musia okrem prvkov, ktoré prenášajú zat'aženie smerom nadol, existovat' aj prvky, ktoré odolajú zat'aženiu pôsobiacemu smerom nahor napr. od sania vetra. [4].

Povrchové napätia, ktoré sú potrebné pre stabilitu a nosnost' konštrukcie, majú za následok okrem bežných vertikálnych síl aj horizontálne sily na kotvy. Toto je cena, ktorú treba zaplatit’ za výhody t’ahaných konštrukcií. 
Schopnost' konštruktéra, ako efektívne zakotvit' tieto horizontálne sily, môže mat' vel'ký vplyv na hospodárnost' konštrukčného systému [5].

Výber oporných bodov definuje tvar konštrukcie. Ich geometria v kombinácii s napätím systému priradeným $\mathrm{k}$ povrchu vedie k tvaru konštrukčného povrchu. Konečný tvar je určený pomocou počítačového programu na vyhl'adávanie tvaru, form-finding, pri ktorom sa hladá minimálna energia plochy pre danú geometriu a nastavené okrajové podmienky. Na zmenu tohto tvaru sa musia zmenit' aj kotviace body alebo vnútorné napätia [5], [6], [7].

Tento príspevok sa zameriava na vplyv asymetrického použitia akčných členov na membránovú štruktúru bez konštrukčného zat’ǎ̌enia. Výsledky článku popisujú správanie sa numerického modelu.

\section{POPIS NUMERICKÉHO MODELU}

Numerický model bol už v niekol'kých článkoch bližšie popísaný, napr. [8], [9], [10]. Vychádza z parametrov experimentálneho zariadenia umiestneného v laboratóriu Technickej univerzity v Košiciach.

Stručne povedané, numerický model hyperbolického paraboloidu bol vytvorený vo výpočtovom prostredí Dlubal RFEM, ktorý obsahuje prídavný modul, na vyhl'adávanie počiatočného tvaru plošných a líniových prvkov, podl'a zvolených okrajových podmienok.

Pozostáva z pevného ocel'ového rámu, ktorého rozmery v osiach rámu sú 3,34 x 3,34 × 2,50 m. Ocel'ový rám sa skladá z rôznych prierezov prvkov a kovových plechových výstuh. Dve kotviace tyče a dva ovládače sú umiestnené $\mathrm{v}$ štyroch rohoch rámu, aby vytvorili základný tvar hyperbolického paraboloidu. Okrajové laná a povrch membrány tvoria hyperbolický paraboloid. Pôdorysný rozmer povrchu membrány je 2,00 × 2,00 m. Prevýšenie povrchu membrány je $1,00 \mathrm{~m}$ so sedlom uprostred. Počiatočný priehyb okrajových lán bol nastavený na $0,20 \mathrm{~m}$. Počiatočné napätie povrchu bolo nastavené na $4,00 \mathrm{kN} / \mathrm{m}$ šírky. Materiálové charakteristiky technickej tkaniny Ferrari Serge Precontraint 502 boli prevzaté od výrobcu. Materiálové charakteristiky ocel'ových a nerezových komponentov boli brané ako bežné normové hodnoty.

Špecifikácia prvkov numerického modelu je znázornená na obrázkoch 1, 2.

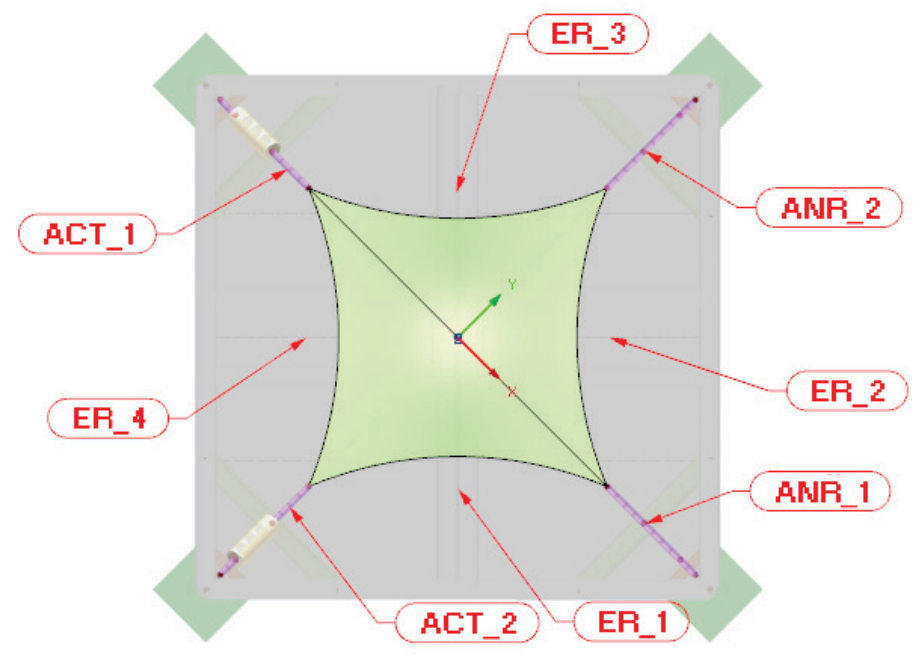

Obr. 1 Špecifikácia prvkov numerického modelu - pohl’ad na pôdorys modelu. 


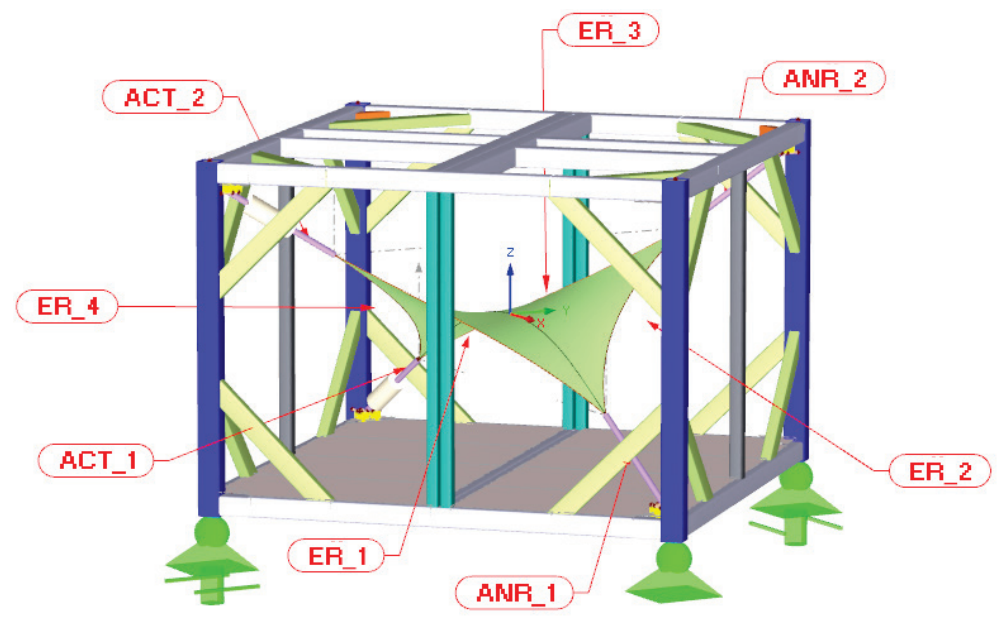

Obr. 2 Špecifikácia prvkov numerického modelu - pohl'ad na model z perspektívy.

\section{NUMERICKÁ ANALÝZA}

Numerická analýza je založená na metóde konečných prvkov (FEM), zatial' čo proces hladania počiatočného tvaru je založený na metóde Update Reference Strategy (URS) siete konečných prvkov [5], čo je matematická homotopická metóda na riešenie inverzného problému.

Na riešenie nelineárnych rovníc bola použitá analýza vel'kých deformácií s Newton-Raphsonovou metódou. Vo všeobecnosti bola vel'kost’ trojuholníkovej siete konečných plošných prvkov stanovená na hodnotu $0,050 \mathrm{~m}$. Delenie pre laná resp. nelineárne prvky bol stanovený na hodnotu 20 dielov na prvok. Delenie pre tlačené a ohýbané prvky bol nastavený na hodnotu 10 dielov na jeden prvok. Bolo nastavené nastavenie globálnych parametrov výpočtu: počet iterácií - 100, počet prírastkov zat’aženia -20 .

Bola nastavená analýza URS. Tolerancia pre konvergenčné kritériá na vyhl’adávanie formulárov bola stanovená na hodnotu 0,50. Rýchlost' konvergencie bola nastavená na hodnotu 0,40 , aby sa spomalila konvergencia a zvýšila sa stabilita výpočtu. Maximálny počet iterácí pre proces hl’adania tvaru bol 200.

V tomto článku nie sú použité zat’ažovacie stavy konštrukčného zat’aženia, iba posun akčných prvkov. Zmena absolútnej dížky akčných prvkov bola použitá na simuláciu ich pohybu. Bolo vytvorených niekol'ko kombinácií pre meniace sa dížky na hornom a spodnom akčnom prvku, aby sa zaznamenalo správanie konštrukčného modelu.

\section{VÝSLEDKY NUMERICKÉHO MODELU}

Pre zaznamenávanie údajov boli v numerickom modeli vytvorené dva rezy, rez A-A a B-B. Rezy boli umiestnené navzájom ortogonálne v pôdoryse membránovej štruktúry medzi jej cípmi. Rezy začínali a končili v akčnom prvku a kotevnej tyči.

Rez A-A zaznamenával údaje o spodnom akčnom prvku, spodnej kotevnej tyči a údaje o povrchu membrány, ktorou rez prechádzal.

Rez B-B zaznamenával údaje o hornom akčnom prvku, hornej kotevnej tyči a údaje o povrchu membrány, ktorou rez prechádzal.

Tento príspevok sa zameriava na tie uzlové body numerického modelu, kde boli umiestnené akčné členy a kotviace tyče, taktiež zaznamenáva údaje o bode v strede povrchu membrány. Grafy znázornené na obrázkoch 3, 5 skúmajú závislost' globálnej, uzlovej deformácie v smere $\mathrm{Z}$ od zmeny posunu akčných prvkov, samostatne pre každý rez. Grafy znázornené na obrázkoch 4, 6 skúmajú závislost’ normálových (axiálnych) síl akčných prvkov /kotevných tyčí od zmeny dížky akčných prkov, taktiež samostatne v každom reze. 


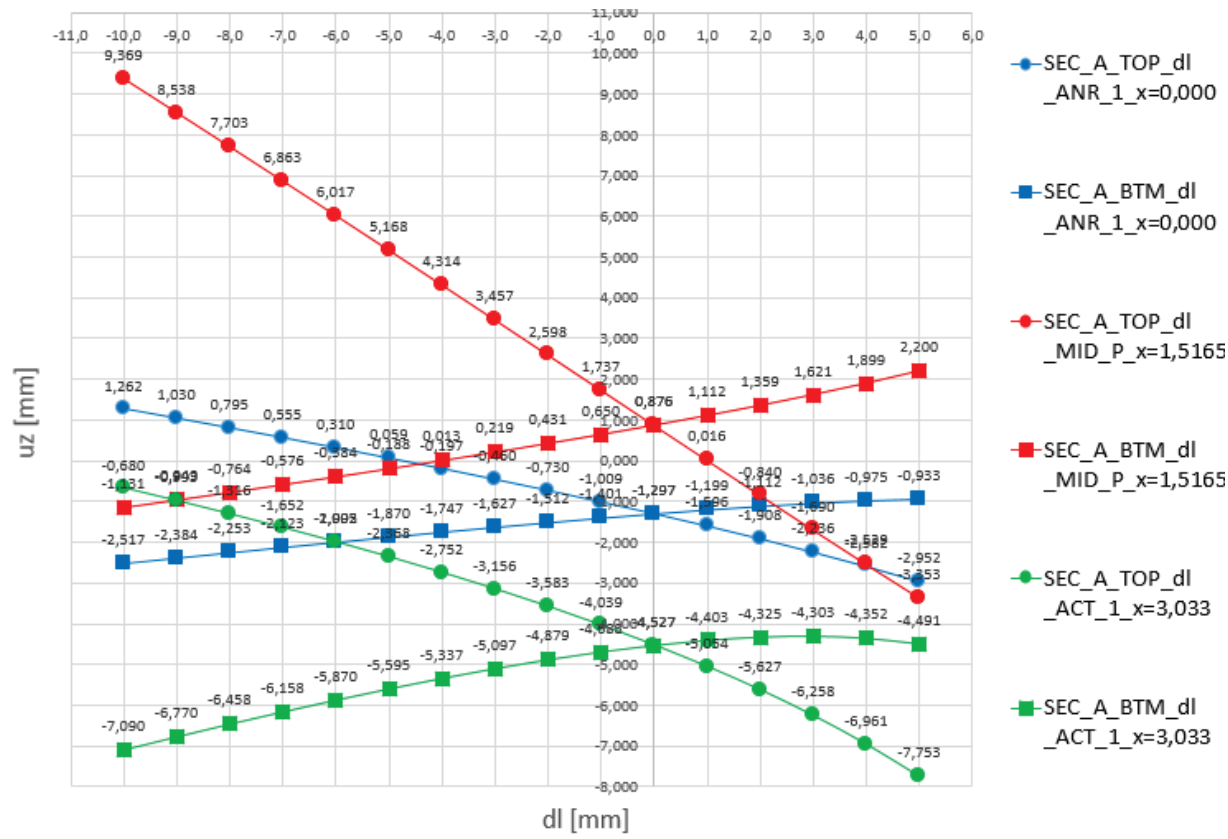

Obr. 3 Závislost' globálnej, uzlovej deformácie v smere Z od zmeny posunu akčných prvkov, pre rez A-A.

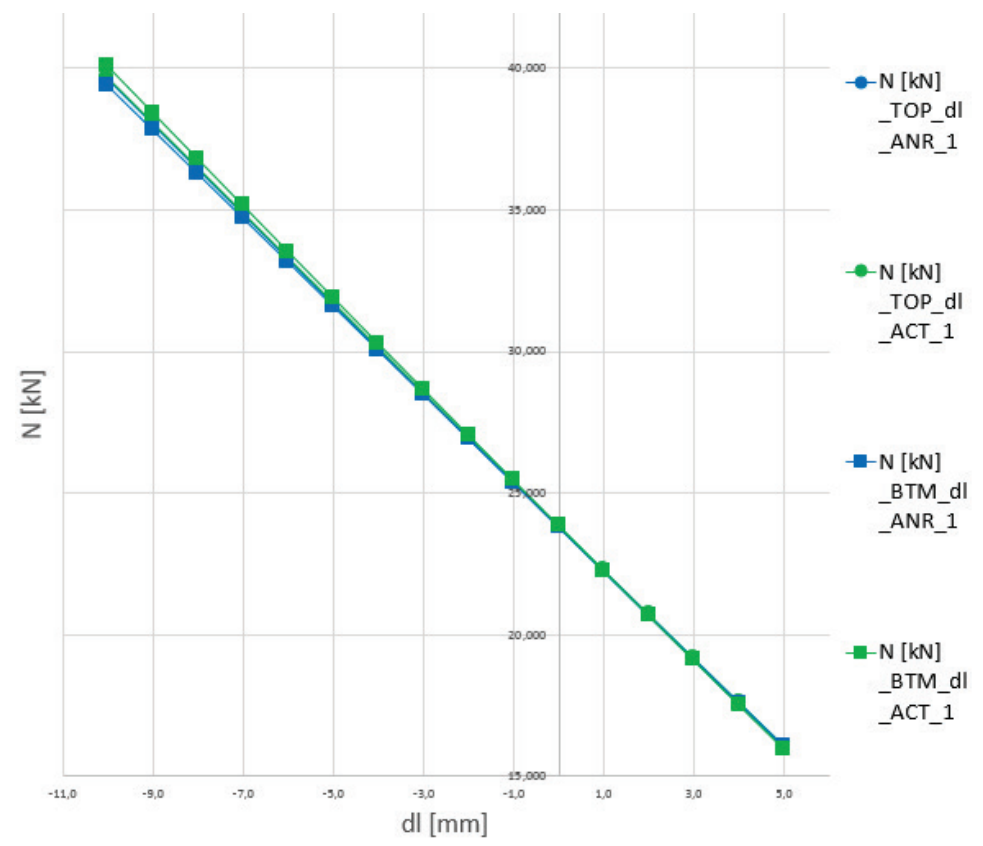

Obr. 4 Závislost’ normálových (axiálnych) síl akčných prvkov /kotevných tyčí od zmeny dížky akčných prkov, pre rez A-A. 


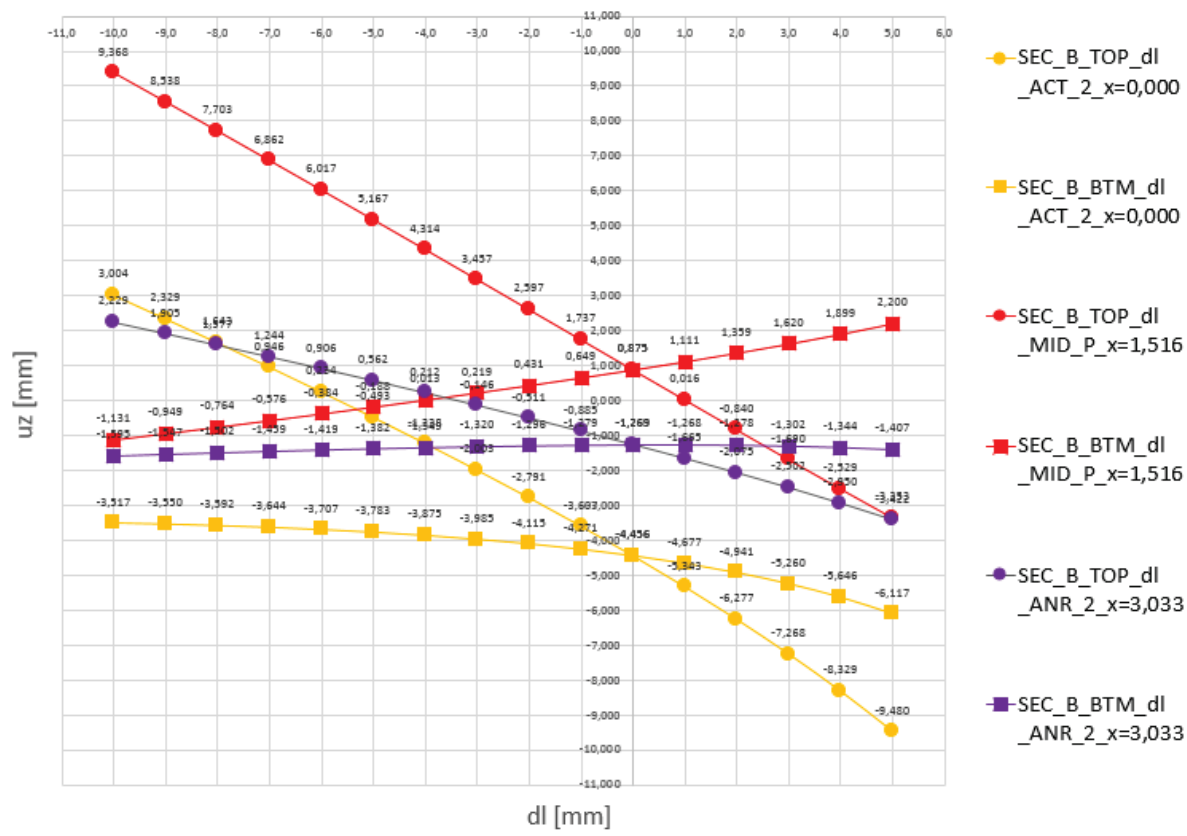

Obr. 5 Závislost' globálnej, uzlovej deformácie v smere Z od zmeny posunu akčných prvkov, pre rez B-B.

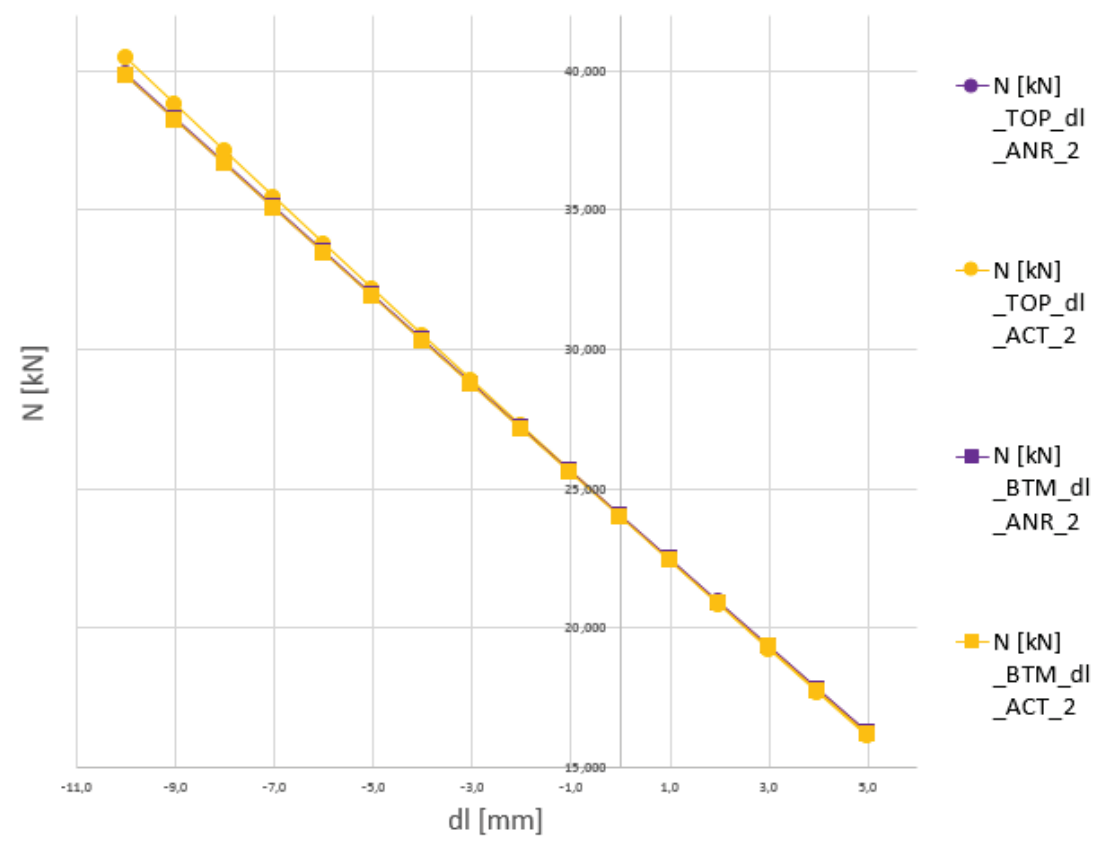

Obr. 6 Závislost' normálových (axiálnych) síl akčných prvkov /kotevných tyčí od zmeny dížky akčných prkov, pre rez B-B. 


\section{ZÁVĚR}

V tomto príspevku bol analyzovaný vplyv neymetrického použitia akčných prvkov na membránovú štruktúru bez konštrukčného zat’aženia.

Zo zobrazených výsledkov, ktoré je možné vidiet’ na grafoch 4, 6, sú normálové sily v ovládačoch a kotevných tyčiach takmer rovnaké v každom jednom kroku zmeny dížky akčného prvku a nezáleží na tom, ktorým z akčných prvkov sa pohybovalo. To dokazuje, že numerický model je v rovnovážnom stave v každej jednej polohe pohonov, ale ako je znázornené na grafoch 3,5, môže byt' vel'mi vel'ký rozdiel medzi jednotlivými závislost'ami globálnej, uzlovej deformácie pri posune horným akčným prvkom a spodným akčným prvkom. Kým skrátenie horného akčného prvku vyvodzuje vel'ký posun sledovaných bodov konštrukcie smerom nahor, skrátenie spodného akčného prvku má skôr stabilizačný charakter pre konštrukciu pri rovnakej úrovni pohybu akčného prvku.

Výsledky článku popisujú správanie sa numerického modelu. Tieto výsledky budú porovnané s výsledkami získanými z experimentálneho zariadenia v laboratóriu.

\section{Poděkování}

Túto prácu podporila Agentúra na podporu výskumu a vývoja na základe zmluvy č. APVV-15-0777 a zároveň aj Slovenská vedecká grantová agentúra na základe zmluvy č. VEGA 1/0129/20.

\section{Použité zdroje}

[1] Kmet' S 2012 Modern cable and membrane constructions Building materials 8 48-52

[2] Foster and Mollaert Marijke 2003 European Design Guide For Tensile Surface Structures (Germany: Tensinet) p 354

[3] Wakefield D S 1999 Engineering analysis of tension structures: theory and practice Engineering Structures 21 680-690

[4] Horst Berger 1999 Form and function of tensile structures for permanent buildings Engineering Structures $21669-679$

[5] Wüchner R and Bletzinger K U 2005 Stress-adapted numerical form finding of pre-stressed surfaces by the updated reference strategy Int. J. Numer. Meth. Eng. 64 143-166

[6] Henrysson, E. : Conceptual design and analysis of membrane structures. Sweden: p.104. 2012. ISSN 1652-8557

[7] Del Grosso A E and Basso P 2010 Adaptive building skin structures Smart Materials and Structures 19 12

[8] Kapolka L 2019 Analysis of an experimental tension structure IOP Conf. Ser.: Mater. Sci. Eng. 566 012014

[9] Kapolka L, Štulerová L and Kmet' S 2019 Adaptive membrane structure - experimental device Assembly of steel constructions workers 19 79-86

[10] Kapolka L 2020 Comparison of results of an adaptive membrane structure with a numerical model IOP Conf. Ser.: Mater. Sci. Eng. 867012015 